\title{
New Medium, Same Story? Gender Gaps in Book Publishing
}

David J. Samuels, University of Minnesota

Dawn Langan Teele, University of Pennsylvania

ABSTRACT Recent research points to a gender gap in journal-article authorship: women are underrepresented. Given that publishing a book remains central to many political scientists' careers, this article explores the extent to which gender publication and citation gaps also exist for books. We find that although the gender publication gap for universitypress books has narrowed over time, it remains larger than for journal articles. We also find that book-authorship patterns do not reflect the shift toward coauthorship observed for journal articles. Conversely, we find no gender citation gap for books written by one woman. However, books coauthored by coed teams or teams of women receive far fewer citations than books written by one man or one woman or by teams of men.

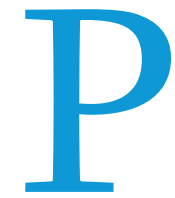
olitical science maintains a robust book tradition. For many scholars, authoring a book is crucial for advancement. Moreover, according to American Political Science Association (APSA) membership data, women remain more likely to belong to qualitative research networks and less likely to participate in quantitative research networks (Shames and Wise 2017; Unkovic, Sen, and Quinn. 2016). Therefore, a book's space to expand arguments and apply a wider variety of methodological approaches than typically seen in top-ranked disciplinary journals might provide a key outlet for women in political science.

This article investigates authorship and citation patterns of political science books. First, building on research that documents a gender gap in journal-article publication in the discipline (Breuning and Sanders 2007; Evans and Moulder 2011; Østby et al. 2013), we explored both the overall proportion of women among authors as well as trends in authorship patterns over time. We found that the "gender gap" for books is slightly wider than for articles: books with only male authors comprise about $69 \%$ of the total, whereas Teele and Thelen $(2017,438)$ found that the proportion was about $65 \%$ for articles in top journals. Furthermore, as with articles, men are overrepresented as both solo authors and collaborators, adding to evidence that women do not benefit equally from the discipline's shift toward coauthorship (Djupe, Smith, and Sokhey 2018). We also found that women's underrepresentation as book authors increases with academic rank. This is important because full professors are the first authors for almost

David J. Samuels (D) is Distinguished McKnight University Professor of political science at the University of Minnesota. He can be reached at dsamuels@umn.edu.

Dawn Langan Teele (D) is associate professor of political science at the University of Pennsylvania. She can be reached at teele.academic@gmail.com. half of all books by academic political scientists. However, within this group, women are only $16 \%$ of first authors, despite holding $28 \%$ of positions in the discipline. To understand the gender publication gap for books, we conducted interviews with acquisitions editors. Key revelations from these conversations include editors' lack of awareness of the problem, lack of systematic data collection about book submissions, the relative opacity of the book-publishing process, and the weight of network effects that may slow women's advancement.

We then examined the impact of books in terms of citations for a random subsample of titles. Somewhat surprisingly, given findings of gender citation gaps for journal articles (Dion, Sumner, and Mitchell 2018; King et al. 2017; Maliniak, Powers, and Walter 2013; Peterson 2018), we found that books authored by one woman receive as many citations as those authored by one man or teams of men. However, books authored by collaborative teams of women or teams of men and women receive far fewer citations, on average, than books by one man or one woman or by teams of men.

For many scholars, a book may be more important for tenure, promotion, and salary decisions than an article at a top journal (or even two or three articles). At the assistant-professor level, for example, a scholar's most notable output may be a book. Given this, gender publishing and citations gaps can have enormous implications for the evolution of women's status in the profession (Alter et al. 2020; Teele 2020)-especially because, in terms of citations, books have far greater impact than journal articles (Samuels 2013). Work on the gender gap in journals has sparked a conversation among journal editors and within APSA about the sources of women's underrepresentation in journals' table of contents (Brown and Samuels 2018). Likewise, we hope our findings generate discussion among and between scholars and 
publishers about the sources and implications of women's underrepresentation among book authors.

\section{DATA}

To assess the distribution of book authorship by gender, we started with what is plausibly the universe of book publishers in the first two categories, we found little difference between commercial and university presses-one or more men write $68.5 \%$ versus $70.6 \%$ of all books. Women are more likely to publish a book on their own with a university press than a commercial press $(20.7 \%$ versus $15.8 \%$ ) but are less likely to publish a book written with another woman with a university press $(1.5 \%$ versus $2.7 \%)$. The most

\section{We found that the "gender gap" for books is slightly wider than for articles: books with only male authors comprise about 69\% of the total, whereas Teele and Thelen $(2017,438)$ found that the proportion was about 65\% for articles in top journals.}

political science: all presses that hosted a booth at the 2016 APSA Annual Meeting, plus any other publisher listed in Garand and Giles (2011). We then compiled lists of books that these publishers classified as "political science" between 2004 and 2015. To do so, we contacted each publisher and requested a list of said books. If we did not receive a response, we compiled the books by scraping publishers' websites. This generated a list of 25,898 books from 34 university and 22 commercial presses.

University presses published about $32 \%(8,250)$ of all books during this period and commercial presses published the remainder $(17,648)$. We assigned a subfield to each title-American politics, international relations (IR), comparative politics, political theory, or methodology-by making educated guesses using titles, abstracts, and/or information that publishers provided about the content of each book. Given the volume of books, we coded subfields only for university-press books. significant difference appears in the last category: women are only about half as likely to write a book with at least one man at a university press than at a commercial press. These figures suggest that women are even less well integrated into collaborative writing networks for university-press books than they are for journal articles, regardless of whether they are working with other women or with men (Teele and Thelen 2017).

About $30 \%$ of university-press books published from 2004 to 2015 had at least one woman's name on the byline. Does that make women underrepresented? Determining a benchmark is not straightforward. On the one hand, the proportion of women among book authors is higher than the share of articles with women as first authors in 10 top journals between 2000 and 2015 (26.7\%). Yet, on the other hand, the proportion is still significantly lower than the two benchmarks that Teele and Thelen (2017) suggested: women's share of political science PhDs

\section{... as solo book authors, women have made significant advances on their own, but not as collaborators-either with women or with men.}

We then classified authors' gender using the "Gender Balance Assessment Tool" created by Jane Lawrence Sumner at the University of Minnesota (Sumner 2018). This program assigns a gender to names probabilistically. Using online searches of authors' websites, we manually checked all names that the program gave lower than $90 \%$ probability and assigned the likeliest gender identity using photographs and gendered pronouns in descriptions of authors' work.

The following discussion reports figures for both commercial and academic presses. However, most of this article focuses on university-press books, which are more important for scholarly advancement. Doing so also provides a reasonable "apples-toapples" comparison to results that Teele and Thelen (2017) presented for journal articles: similar to articles but unlike most commercial-press books, university-press books are peer reviewed. ${ }^{1}$

\section{RESULTS: GENDER PUBLICATION GAPS}

Combining university and commercial presses, books with only male authors comprise $69.1 \%$ of the total. Books with only women among authors comprise only $19.6 \%$, and those with mixed-gender author teams comprise $11.2 \%$. Table 1 divides the data into university and commercial presses, according to one of five categories: man solo author, woman solo author, all-men coauthorship, allwomen coauthorship, and mixed-gender coauthorship. Combining granted (38\% in 2016) and women's share of APSA members $(38 \%$ in 2015). ${ }^{2}$

It is worth noting that the gender gap in book publishing has narrowed somewhat over time: overall, the total share of women among authors rose by one third between 2004 and 2015, from $21 \%$ to almost $28 \%$. However, this is still less than the proportion of women in the discipline. Figure 1 tracks the time trends of the five authorship categories for university presses. In the early 200os, books by one man accounted for $63 \%$ of the total; however, by 2015 , that proportion had declined to $54 \%$. Most of the increase in the share of women among authors came from growth in the proportion of women's solo publications (19\% to $23 \%$ ) and participation in mixed-gender teams ( $5 \%$ to $8 \%$ ).

This minor increase in the proportion of mixed-gender collaborations is the only evidence of an increase in women's coauthorship of books. Yet, in stark contrast to patterns for articles described by Teele and Thelen (2017), the proportion of books coauthored by either men-only or women-only teams has barely increased in recent years. Although the proportion of mixedgender collaborations has increased to $8 \%$ of the total, it is still only one third the level observed for mixed-gender coauthorship in top journals (24.5\%). In short, as solo book authors, women have made significant advances on their own (20\% of the book total versus only $15 \%$ of the journal-article total), but not as collaborators-either with women or with men. 
The shrinking gender publication gap over time raises the question of whether women are more or less underrepresented in different ranks. From the 5,631 university-press books published between 2004 and 2012 (i.e., six years before our research because we also collected information on citations gaps), we drew a random sample of 1,170 titles: 1,00o from the full dataset, balanced on authorship pattern and subfield, and an additional 170 randomly oversampled from coed and all-women teams, which have relatively fewer books. This provided a sample of $21 \%$ of the total. We kept all books authored by academic political scientists (about 6\% were not) but eliminated reprints, including those written by long-deceased scholars (137) and deleting paperback editions of previously published books ( 65 more), resulting in 613 books.

Using biographical information on each book's back cover (cross-checked with institutional or personal web pages), we collected information on the rank of first authors at the time of the book's publication. We found that the gender publication gap, when compared with the proportions of women at each rank, is wider in more senior ranks: at the assistant-professor level, women are $38 \%$ of first authors and $43 \%$ of APSA members; at the associate-professor level, $35 \%$ of first authors and $40 \%$ of APSA members; and at the full-professor level, only $16 \%$ of first authors and $28.6 \%$ of APSA members.

\section{Subfield Patterns}

Table 2 addresses the question of whether gender publication gaps vary across subfields. Baseline information on women's share in subfields is from field-specific APSA memberships listed in Hardt et al. (2019). IR has the smallest share of women among book authors (21\%), whereas comparative politics has the largest (28\%). Yet, in both groups, there is an approximate 14-point gap in women's book publications vis-à-vis their presence in the subfield. There are relatively few methodology books; within that subfield, women authors are $21 \%$ of the total. This means that in methodology, women comprise a

Table 1

Distribution of Authorship for Commercial and University Presses

Commercial Presses

University Presses

\begin{tabular}{lcccc} 
& Frequency & Percentage & Frequency & Percentage \\
\hline One Man & 9,109 & 51.6 & 4,706 & 57.0 \\
\hline Coauthored, All Men & 2,982 & 16.9 & 1,112 & 13.5 \\
\hline One Woman & 2,784 & 15.8 & 1,689 & 122 \\
\hline Coauthored, All Women & 470 & 2.7 & 6.5 & 1.5 \\
\hline Coauthored, Mixed Gender & 2,303 & 13.1 & 8,250 & 7.5 \\
\hline Totals & 17,648 & 100 & 8.20
\end{tabular}

Figure 1

Authorship Patterns Over Time, University Presses

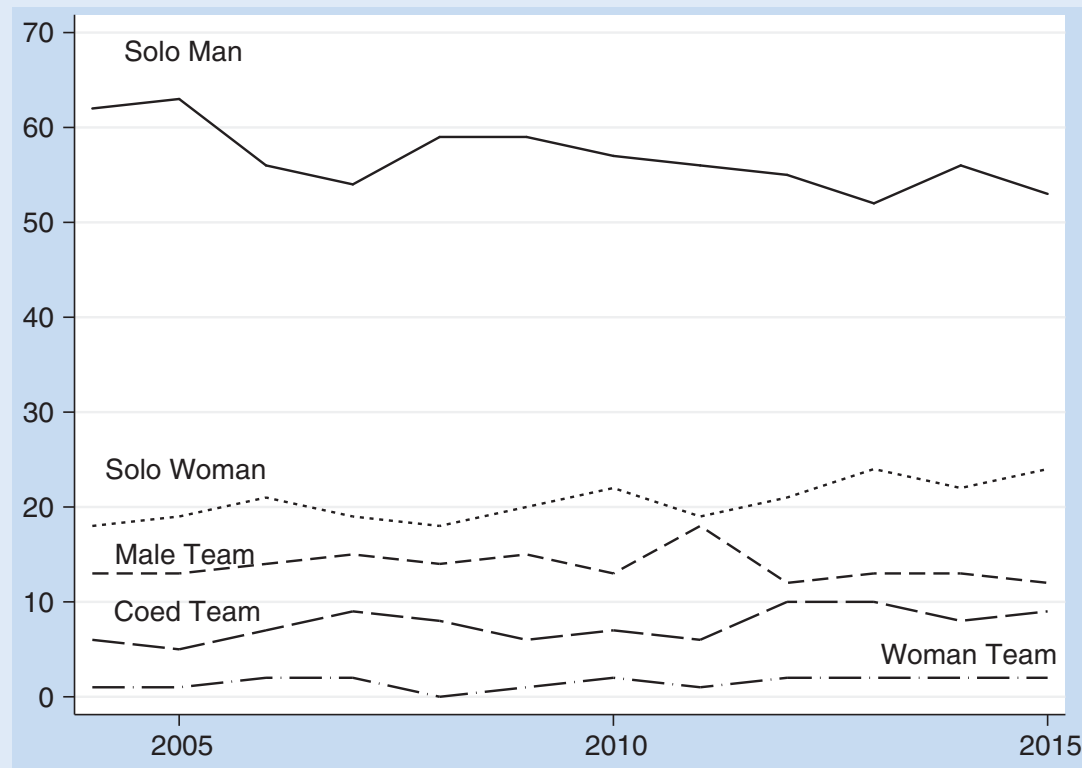


larger proportion of book authors than APSA members in that subfield; however, we should not overstate this finding given the small number of methods books. In all other subfields, women are underrepresented among authors relative to their numbers in those fields.

Figure 2 explores the proportion of women among authors by subfield over time. We excluded methodology because low numbers mean that the publication of a single book by a woman in a given year throws off the proportions. The figure shows that in political theory, the proportion of women among authors has remained constant. In contrast, the proportion of women among authors has increased in American politics ( $20 \%$ to $25 \%$ ), IR ( $18 \%$ to $25 \%$ ), and-most notably-in comparative politics ( $22 \%$ to $32 \%$ ). However, despite these gains, the proportion of women among authors remains lower than the contemporary proportion of women in each subfield.

\section{Explaining the Gender Book-Publication Gap}

As in journal articles, a gender gap in book publishing exists in political science: women publish relatively fewer books than their numbers in the discipline might predict. Moreover, although the gender book-publication gap has narrowed over time, it remains larger than for articles in top journals by about $5 \%$. Most of women's relative gains have come as solo authors, but they remain far less likely to collaborate on books than on articles. Within subfields, the gender book-publication gap is most significant and has remained unchanged in political theory. It has narrowed somewhat over time in IR and American politics and mostly in comparative politics.

Table 2

Summary Statistics by Subfield, University Presses

\begin{tabular}{|c|c|c|c|c|c|}
\hline Subfield & N & $\begin{array}{l}\text { Subfield Books } \\
\% \text { of Total }\end{array}$ & $\begin{array}{l}\text { Women among } \\
\text { Authors }(\%)\end{array}$ & $\begin{array}{l}\text { Women in } \\
\text { Subfield (\%) }\end{array}$ & Subfield Gap (Points) \\
\hline American Politics & 1,943 & 23.6 & 24.3 & 35 & -10.7 \\
\hline IR & 1,662 & 20.2 & 22.1 & 36 & -13.9 \\
\hline Comparative Politics & 2,601 & 31.5 & 28.6 & 43 & -14.4 \\
\hline Political Theory & 954 & 11.6 & 25.5 & 32 & -6.5 \\
\hline Methods & 92 & 1.1 & 21.5 & 19 & 2.5 \\
\hline (Unknown) & 619 & 8.0 & 23.6 & & \\
\hline Non-Political Science Books (Removed) & $(379)$ & & & & \\
\hline Total Books & 8,250 & 100 & & & \\
\hline
\end{tabular}

\section{Figure 2}

Percentage of Women Among Authors by Subfield, 2004-2016
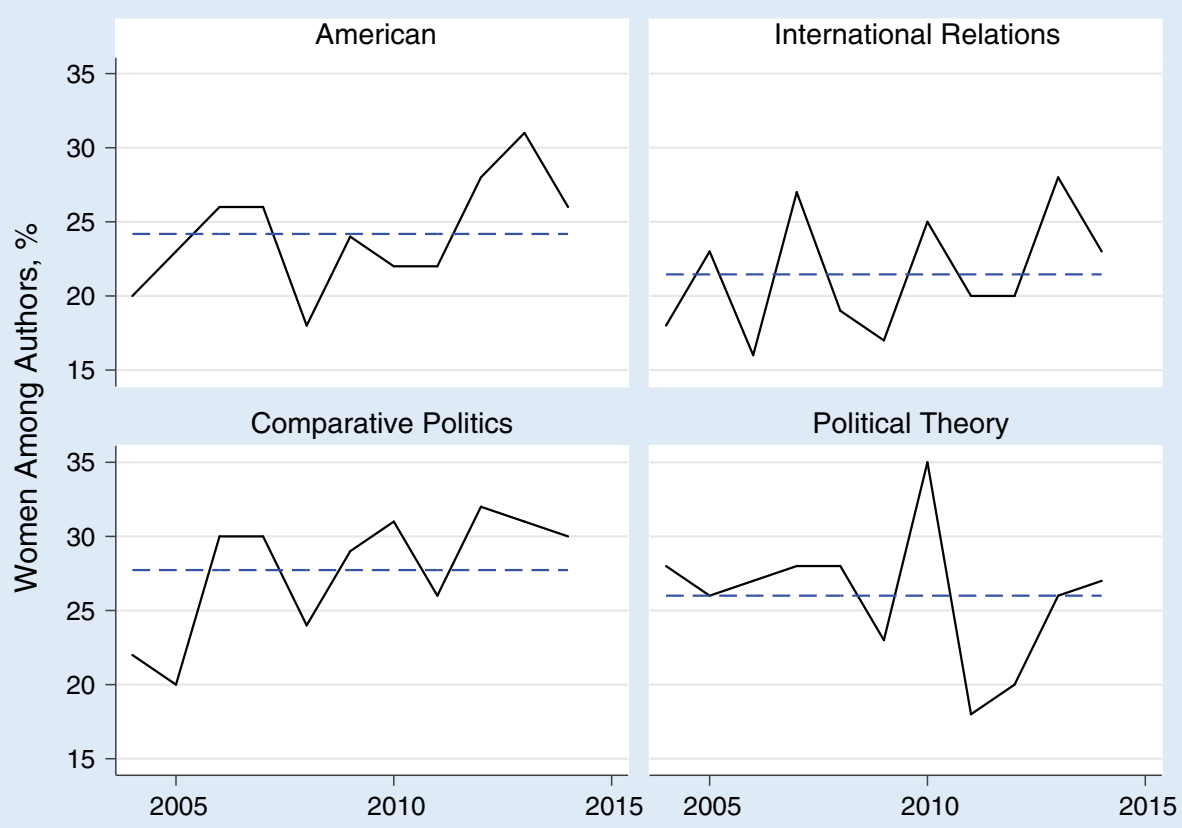

Note: Dotted lines represent women's membership in the subfield reported in Hardt et al. 2019. 
To better understand the roots of the book-publication gender gap, we conducted informal telephone and Internet audio interviews with political science acquisitions editors from one commercial press and seven university presses (three men and five women). ${ }^{3}$ These professionals had at least 175 combined years of editorial experience. Our discussions with them suggested several reasons why a book gender gap may exist.

First, in contrast to the attention focused on the gender balance of article publishing in recent years, which in turn raised attention among journal editors (Brown and Samuels 2018), our interviews revealed that the gender balance of book authors is not yet a topic of wide concern among book editors. One editor affirmed that "Nobody ever raises the issue; I don't even know who I'd raise the issue with. We just assume we are doing alright." Another stated that "There has never been a discussion in five years at [our press] about finding more women. Maybe we need to do more of that, be more proactive." Even at a press where the issue of gender balance has been discussed in recent years, the editor could not confirm that anything had actually changed: "I don't really know-I think my author list is pretty balanced... [but] it's possible that there are patterns I just don't pick up."

Second, even for editors who stated that gender balance is a concern at their press, book editors lack the type of information that journal editors possess that could help identify a gender gap. It is not only that books are submitted and evaluated differently from journal articles. The issue is that every editor we spoke to confirmed that presses keep no records at all of information relevant to the editorial process-including the number of submissions, rejections, and acceptances or any type of authordemographic information. Given this, book editors could provide only rough estimates of the number of submissions per year or the gender balance of published books. (Two had counted the number of books they had published in the previous year and the proportion of women authors immediately before the interview.) Given the relative lack of attention to the issue and their lack of information, editors must rely on guesswork to track the balance by gender (or rank or ethnicity) of published books-whether the press receives a few dozen or several hundred submissions per year.

Third, book editors' professional incentives also may slow responses to demands for attention to a gender gap in publishing. The editorial process for book publication is not only less transparent than the (already opaque) article publication process; book editors also face relatively fewer incentives to improve transparency. They are not nominated and hired by teams of professional colleagues as are many journal editors, they do not have to publish annual editors' reports, and they do not answer to editorial boards of professional colleagues. Their professional incentives also differ from those of journal editors, who typically serve relatively brief terms and then return to their academic positions in which they must continue to produce journal articles and book manuscripts.

Fourth, because they are not colleagues, book editors do not participate as directly in APSA or other professional association task forces or in other activities focused on bringing attention and conducting research on issues related to women's professional advancement.

Factors specific to the book-publishing process also may contribute to the gender gap in book publications in political science. Most important, book and journal editors differ in their discretion to solicit and publish manuscripts. As our interviewees confirmed, unlike journal articles, most book editors solicit a sizeable proportion of manuscripts that they eventually publish, and they publish relatively few submissions that arrive "over the transom." Most editors described the creation of their lists in an alchemic way, suggesting that their experience has given them "a good nose" about which books to publish. They also often noted that book publishing is a business, meaning that they need to acquire titles they believe will sell (although they acknowledge that a few books with high sales subsidize the publication of most others). Yet, when pressed, not a single editor suggested that they had evidence that women's books sold fewer copies than men's, and several could immediately name books bylined by women that sold very well.

Editors also acknowledged that the nature of book publishing might slow down change because it can perpetuate an existing network of authors and their advisees. Due to the slow pace of cohort replacement, this may retard growth in the proportion of women authors. After all, to the extent that women are less central to a network of senior male scholars who publish books, fewer women are likely to be recommended to publishers. In addition, the single-blind peer-review process for books-in which reviewers know the author-may hold women to tougher standards than men, resulting in their manuscripts taking longer in the review and revision phases (Hengel 2017). This "time tax" could be much longer than for any single article, further undermining women's long-term productivity relative to men.

A potential manuscript "submission gap"-driven by both publishers' and senior male scholars' networks-also may help to explain the book "publication gap." In addition to network effects, women may write and submit fewer book manuscripts due to perpetually high academic service loads (Alter et al. 2020); child-bearing and -rearing duties may reduce women's productivity (i.e., the "mommy penalty"); and women might produce higher-quality work that takes more time (Hengel 2017). These factors may make women more risk averse. For example, given that women are relatively more underrepresented at some presses than others (see appendix figure A.2), just as with journals, it is possible that women perceive the likelihood of success at those presses differently from others (Brown et al. 2020; Djupe, Smith, and Sokhey 2018). Without editorial data about the number of submissions that presses receive, the number that are sent out for review, and the publication trajectories of each reviewed manuscript, several of our hypotheses are difficult if not impossible to test. Nevertheless, we encourage editors to conduct internal audits of the nature explored in Brown and Samuels (2018).

\section{RESULTS: GENDER CITATION GAPS}

Our second focus in this article concerns whether books written by men and women receive different levels of recognition, as measured by citations. Given the growing use of tools such as Google Scholar, this is an important question. Within our subsample of 613 books by academic political scientists that were not reprints or paperback editions, 72 were written by a coed team (12\%), 12 by an all-woman team ( $2 \%), 108$ by women working alone ( $18 \%), 81$ by an all-man team (13\%), and 340 by men working alone (55\%). We were able to find citation information for all but five of these books.

Figure 3 provides average citation counts from Google Scholar for political science titles after six and at least 10 years for these authorship categories. The figure presents citation counts from 
Google Scholar for a random sample of (non-reprint) books written by academic political scientists. The first column calculates the citation count six years post-publication. The second column calculates the all-time citation averages for books older than 10 years at the time of data collection.

We found surprising patterns. First, six years post-publication, books written by women working alone do as well, on average, as those written by one man or teams of men. (A t-test for the difference written by teams of women. Mixed-authorship teams also fared poorly in terms of citation counts after more than 10 years (i.e., the one-sided p-value for difference of means between men's teams and coed teams is o.034). These gaps are substantially larger than what has been found for articles. For example, Maliniak, Powers, and Walter (2013) found that by the 20oos, articles authored by women received about $90 \%$ of the citations of articles authored by men.

\section{...books written by women working alone do as well, on average, as those written by one man or teams of men.}

of means for books written by one woman versus one man or teams of men failed to reject the null of no difference.) Six years out, books by teams of men perform slightly better than books written by men working alone (i.e., the one-sided p-value is o.075). Books written by coed teams lag behind all of the other categories except books written by all-women teams, which fare the worst. Indeed, books written by teams of women appear to be poorly recognized, receiving only 35 citations, on average, six years after publication compared with an average of 82 for books written by men working alone and 89 for those written by women working alone. ${ }^{4}$

Other striking gaps emerged when we considered books that are at least 10 years old. Overall, books by teams of men accrue the most recognition, followed by books bylined by a man working alone. Although there are no statistical differences between these two categories and books written by women working alone, coed teams and all-women teams again performed substantively worse. After more than 10 years, books written by teams of men received seven times the number of citations as books

\section{Academic Rank and Gender Citation Gaps}

One concern with exploring gender citation gaps by authorship type is that-as noted previously-not only are men and women unequally distributed across professional ranks, the gender publication gap also is larger at higher academic ranks. As Peterson (2018) noted, the citation gap for journal articles has narrowed in recent years to more closely match the gender distribution of scholars. He suggested that this is due to a legacy of male dominance in the discipline, which is changing slowly as citation norms change and as more women advance up the ranks. Does the citation gap also widen as authors "age" in our dataset for all the well-known reasons, such as that women are less likely to appear on graduate syllabi and men are more likely to self-cite?

Figure 4 reveals few differences in citation patterns for books based on gender and rank. Within ranks, books with a woman as the first author do not receive less recognition than books with a man as the first author (there are no statistically significant

\section{Figure 3}

\section{Citation Patterns by Type of Authorship}

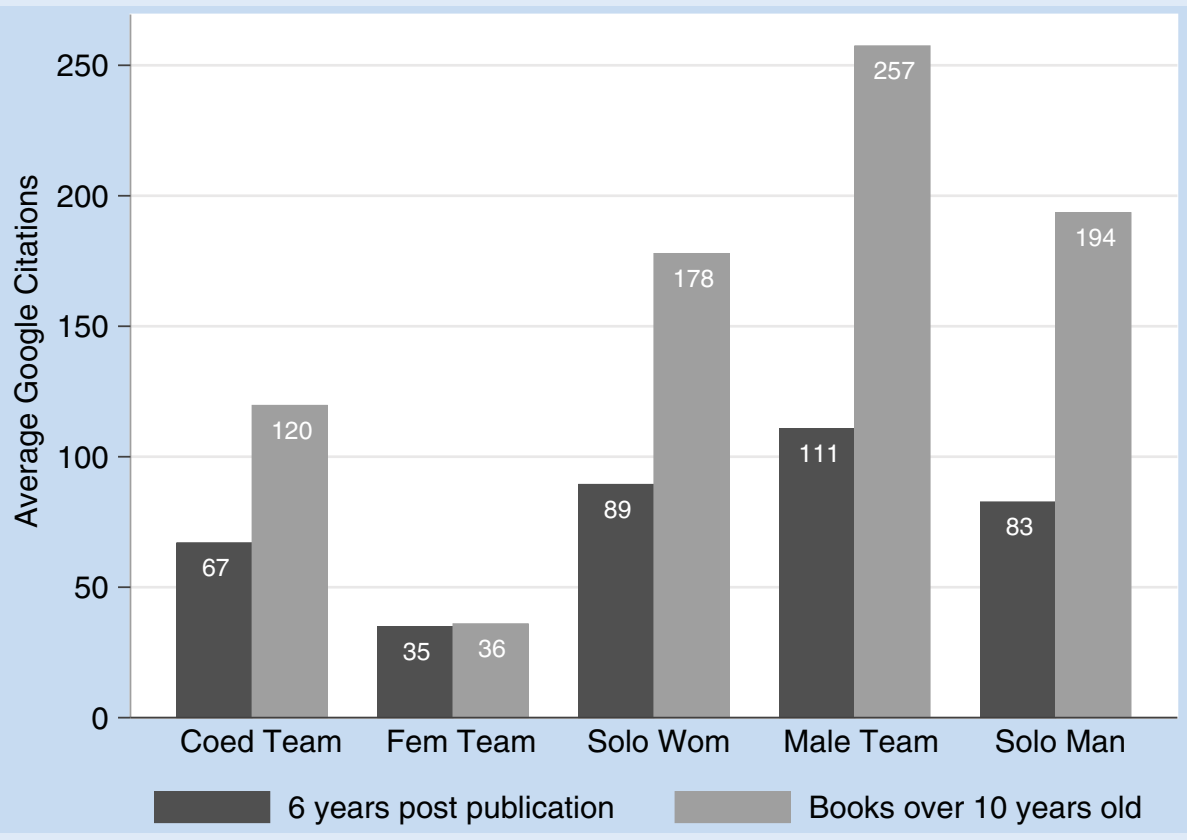




\section{Figure 4 \\ Citation Patterns by Rank and Gender}

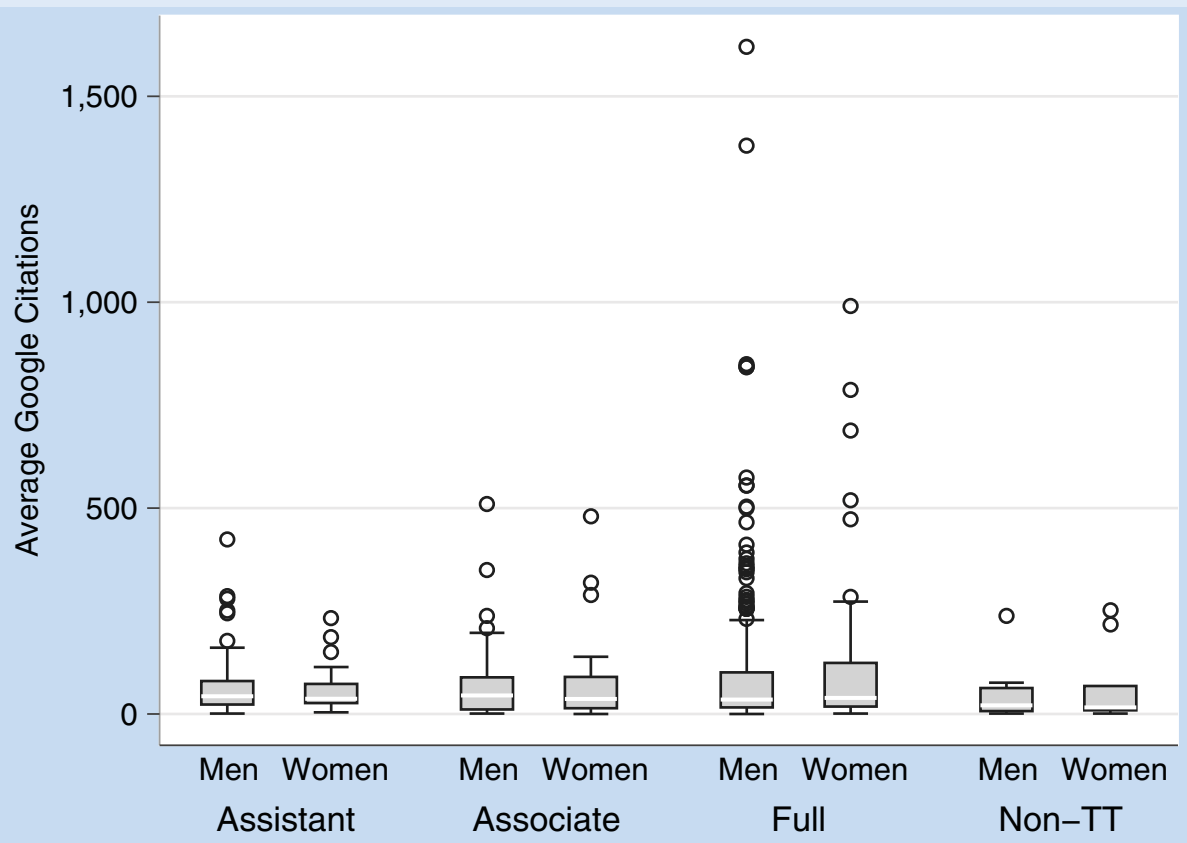

Note: Analyzes for random sample of political science books six years post-publication.

p-values using difference of means tests). However, books with men as first authors are more likely to fall outside of the interquartile range of the distribution of citations at every rank. In other words, there are more highly cited outliers among the books on which men's names appear first.

In summary, we found no consistent gender citation gap for books. Books by one woman receive about the same number of citations both six and 10 years post-publication as books by one man or teams of men. However, books by mixed-gender teams fare somewhat worse than others, and books by teams of women fare the worst. We also found no clear citation gaps within ranks. It is not clear why these patterns emerge. There is no clear reason why, for example, books by teams of women might be "niche" books whereas books by one woman would not.

\section{DISCUSSION}

Our findings include both good news and bad. To begin with the relatively good news, in contrast to results for journal articles, there are no clear gender citation gaps for books-at least those written by one woman. However, books by teams of women or by mixedgender teams receive fewer citations than books by one woman or one man or by teams of men; perhaps this reflects women's relatively weaker integration into collaborative research networks. Yet, there is some bad news: although most women receive relatively equal recognition for the books they write, and although the gender book-publication gap has narrowed over time in most subfields, women are still writing fewer books than men, and men's books are more likely to be among the most "highly cited" in the discipline over the long term. Women remain underrepresented as book authors relative to their numbers in the discipline-across ranks and across subfields-and remain relatively more underrepresented as book authors than as journal authors.

\section{DATA AVAILABILITY STATEMENT}

Replication materials can be found at https://doi.org/10.7910/ DVN/HN1I8Y.

\section{ACKNOWLEDGMENTS}

We thank Paula Armendariz and Carly Coons for research assistance, and Lisa Baldez, Nadia Brown, Yusaku Horiuchi, Mala Htun, Josh Kalla, Dorothy Kronick, Jane Lawrence Sumner, Amy Erica Smith, and the anonymous reviewers for their comments. :

\section{NOTES}

1. For replication data, see Samuels and Teele (2020).

2. Information on membership is from the 2015 APSA member survey. The information was provided by Erin McGrath, a researcher at APSA, via email on January 20, 2020.

3. The sample was nonrandom but aimed to include both small and large university presses, presses with limited and extensive lists in political science, and one representative of a large commercial press for contrast. The hour-long interviews were conducted in September and October 2019, and interviewees were guaranteed anonymity.

4. We oversampled to collect information on all of the books written by teams of women. In the group of books by academic political scientists, there were only seven, too few to calculate meaningful test statistics.

\section{REFERE N CES}

Alter, Karen, Jean Clipperton, Emily Schraudenbach, and Laura Rozier . 2020. "Gender and Status in American Political Science: Who Determines Whether a Scholar Is Noteworthy?" Perspectives on Politics. Available at https://doi. org/10.1017/S1537592719004985.

Breuning, Marijke, and Kathryn Sanders. 2007. "Gender and Journal Authorship in Eight Prestigious Political Science Journals." PS: Political Science \& Politics 40 (2) 347-51.

Brown, Nadia, and David J. Samuels. 2018. "Gender in the Journals, Continued: Evidence from Five Political Science Journals." PS: Political Science \& Politics 51 (4): $847-48$. 
Brown, Nadia, Yusaku Horiuchi, Mala N. Htun, and David J. Samuels. 2020. "Gender Gaps in Perceptions of Political Science Journals.” PS: Political Science \& Politics 53 (1): 114-21.

Dion, Michelle, Jane Lawrence Sumner, and Sara McLaughlin Mitchell. 2018. "Gendered Citation Patterns Across Political Science and Social Science Methodology Fields." Political Analysis 26 (3): 312-27.

Djupe, Paul, Amy Erica Smith, and Anand Edward Sokhey. 2018. "Explaining Gender in the Journals: How Submission Practices Affect Publication Patterns in Political Science." PS: Political Science \& Politics: 52 (1): 71-77.

Evans, Heather, and Ashley Moulder. 2011. "Reflecting on a Decade of Women's Publications in Four Top Political Science Journals." PS: Political Science E Politics 44 (4): 793-98.

Garand, James C., and Michael W. Giles. 2011. "Ranking Scholarly Publishers in Political Science: An Alternative Approach." PS: Political Science \& Politics 44 (2): $375-83$.

Hardt, Heidi, Hannah June Kim, Amy Erica Smith, and Philippe Meister. 2019. "The Gender Readings Gap in Political Science.” Journal of Politics 81 (4): 1528-32.

Hengel, Erin. 2017. "Publishing While Female: Are Women Held to Higher Standards? Evidence from Peer Review." Cambridge Working Papers in Economics 1753. University of Cambridge: Faculty of Economics.

King, Molly M., Carl T. Bergstrom, Shelley J. Correll, Jennifer Jacquet, and Jevin D. West. 2017. "Men Set Their Own Cites High: Gender and Self-Citation Across Fields and Over Time." Socius 3. Available at https://

doi.org/10.1177/2378023117738903.

Maliniak, Daniel, Ryan Powers, and Barbara F. Walter. 2013. "The Gender Citation Gap in International Relations." International Organization 67 (4): 889-922.

Mitchell, Sara Mclaughlin, Samantha Lange, and Holly Brus. 2013. "Gendered Citation Patterns in International Relations Journals." International Studies Perspectives 14 (4): 485-92.
Østby, Gudrun, Håvard Strand, Ragnhild Nordås, and Nils Petter Gleditsch. 2013. "Gender Gap or Gender Bias in Peace Research? Publication Patterns and Citation Rates for Journal of Peace Research, 1983-2008." International Studies Perspectives 14 (4): 493-506.

Peterson, David A. M. 2018. "Historical Disparities and Gendered Citation Patterns." Political Analysis 26 (3): 338-44.

Samuels, David J. 2013. “Book Citations Count.” PS: Political Science \& Politics 46 (4): 785-90.

Samuels, David J., and Dawn Langan Teele. 2020. "Replication Data for "New Medium, Same Story? Gender Gaps in Book Publishing.” DOI: 10.7910/DVN/ HN1I8Y.

Shames, Shauna, and Tess Wise. 2017. "Gender Diversity and Methods in Political Science: A Theory of Selection and Survival Biases." PS: Political Science \& Politics $50(3): 811-23$.

Sumner, Jane Lawrence. 2018. "The Gender Balance Assessment Tool (GBAT): A Web-Based Tool for Estimating Gender Balance in Syllabi and Bibliographies." PS: Political Science \& Politics 51 (2): 396-400.

Teele, Dawn Langan. 2020. "What's Wrong with Replicating the Old Boy's Network?" In The Production of Knowledge: Enhancing Progress in Social Science, ed. Colin Elman, John Gerring, and James Mahoney. Cambridge: Cambridge University Press. Forthcoming.

Teele, Dawn Langan, and Kathleen Thelen. 2017. "Gender in the Journals: Methodology, Coauthorship, and Publication Patterns in Political Science's Flagship Journals." PS: Political Science \& Politics 50 (2): 433-47.

Unkovic, Cait, Maya Sen, and Kevin M. Quinn. 2016. "Does Encouragement Matter in Improving Gender Imbalances in Technical Fields? Evidence from a Randomized Controlled Trial." PLOS One 11 (4): 1-15.

\section{APPENDIX: DESCRIPTIVE STATISTICS BY PRESS}

Figure A.1 shows the aggregate proportion of women among all authors for each university press. Presses at the low end of the scale include Yale, Missouri, Kansas, and Kentucky, none of which break 15\%. Minnesota, Syracuse, and Illinois are the highest, each with at least $45 \%$ of authors who are women.

Has the gender gap narrowed over time at particular presses? Figure A.2 lists the proportion of women authors over time for each university press. At most presses, the proportion is fairly constant; at others, we see an increase. For example, Cambridge averaged $27 \%$ over the sample but reached $50 \%$ in 2015 . 
Figure A.1

Proportion of Women Among Authors for University Presses, 2004-2015

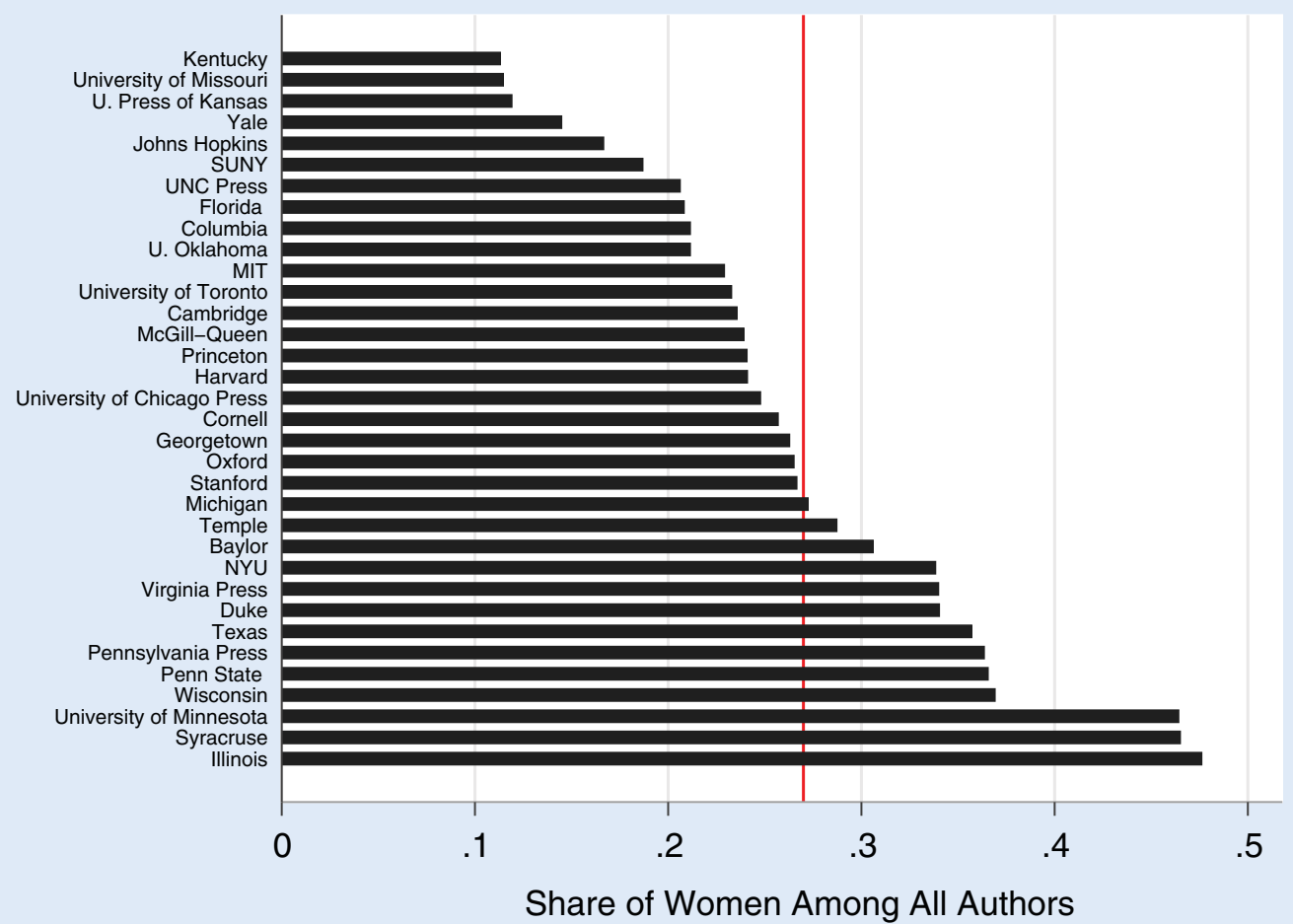

Note: Numbers by each press name represent the average share of women among authors in the period.

Figure A.2

Women as a Percentage of Authors by University Press, Over Time

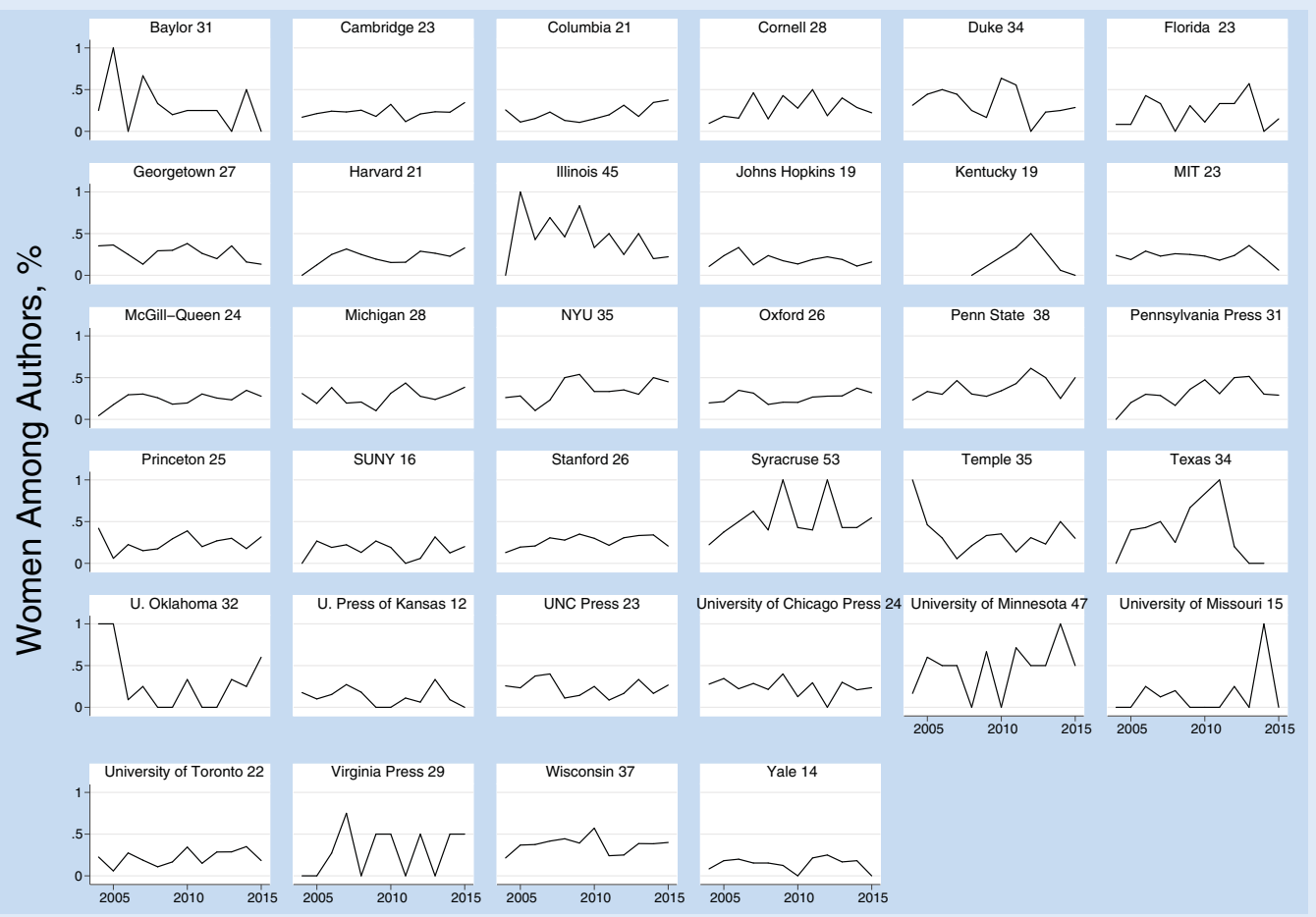




\section{Achieving Diversity and Inclusion in Political Science}

\section{Diversity and Inclusion Programs}

The American Political Science Association has several major programs aimed at enhancing diversity within the discipline and identifying and aiding students and faculty from underrepresented backgrounds in the political science field. These programs include:

Ralph Bunche Summer Institute (RBSI) (Undergraduate Juniors)

The RBSI Program is an annual five-week program designed to introduce to the world of doctoral study in political science to those undergraduate students from under-represented racial/ethnic groups or those interested in broadening participation in political science and pursuing scholarship on issues affecting underrepresented groups or issues of tribal sovereignty and governance. Application deadline: January of each year. For more information, visit www.apsanet.org/rbsi.

APSA Minority Fellows Program (MFP) (Undergraduate Seniors or MA and PhD students) (Fall Cycle for seniors and MA Students, Spring Cycle for PhD students) MFP is a fellowship competition for those applying to graduate school, designed to increase the number of individuals from under-represented backgrounds with PhD's in political science. Application deadline: October and March of each year. For more information, visit www.apsanet.org/mfp.

Minority Student Recruitment Program (MSRP) (Undergraduates and Departmental members) The MSRP was created to identify undergraduate students from under-represented backgrounds who are interested in, or show potential for, graduate study and, ultimately, to help further diversify the political science profession. For more information, visit www.apsanet.org/msrp.

\section{APSA Mentoring Program}

The Mentoring Program connects undergraduate, graduate students, and junior faculty to experienced and senior members of the profession for professional development mentoring. APSA membership is required for mentors. To request a mentor or be a mentor, visit www.apsanet.org/mentor.

\section{APSA Status Committees}

APSA Status Committees develop and promote agendas and activities concerning the professional development and current status of under-represented communities within the political science discipline. For a listing of all APSA status committees, visit www.apsanet.org/status-committees.

For more information on all Diversity and Inclusion Programs, visit us online at www.apsanet.org/ diversityprograms. Please contact Kimberly Mealy, PhD, Senior Director of Diversity and Inclusion Programs with any questions: kmealy@apsanet.org.

To contribute to an APSA Fund, such as the Ralph Bunche Endowment Fund or the Hanes Walton Jr. Fund, visit us at www.apsanet.org/donate. 